\title{
Is High Housing Price the Responsibility of the Government?
}

\author{
Zhang Xuefeng \\ School of Economics and Management \\ North China University of Technology \\ Beijing, China \\ E-mail: zxf511@163.com
}

\begin{abstract}
Nearly 20 municipal governments have issued a house purchase limitation or purchase of upgrades to control housing prices rose too fast. Is it that the high house price is the responsibility of the government? This paper constructs the game model to answer the question. The study obtains the government to choose the latter condition under the two kinds of decision making, which is to maximize the financial income and maximize the social welfare. It also analyzes the policy implications of the land price and the real estate tax rate in order to achieve the stated goal. The study found that the tax rate is greater than the entire social welfare maximization of the real estate tax rate when the government does not consider the interests of real estate developers. When the optimal land leasing that is considered the social welfare maximization by the government is less than or equal to the land leasing without considering the interests of real estate developers land leasing, the government should reduce the collection of land leasing to increase the interests of real estate developers and lower tax rates to increase the interests of consumers. On the contrary, the government should increase the land leasing fee by increasing the land transfer to increase the interests of consumers and higher tax rates to increase government revenue.
\end{abstract}

\section{Keywords_-High housing prices; Game; Land leasing}

\section{INTRODUCTION}

With the development of China's market economy, the real estate industry in China's economic status has been rising, so the central government clearly put the real estate industry as a new growth point of the national economy. The development of the real estate industry is not only related to the improvement of people's living standard, but also directly affects the healthy development of China's macro economy. However, the rapid economic development has also accelerated the demand for urban land. Land as a scarce resource has contributed to high prices because of the relative reduction of residential development land. Incorporated Administrative Agency (RIETI) published an article which called on China to guard against the real estate bubble in April 28th. China's housing prices began a new round of soaring, especially in the first tier cities such as Beijing, Shanghai, Guangzhou, Shenzhen and so on.

In the short term, the recovery of the real estate market will help promote China's economic growth and improve international commodity prices. Data show that housing investment accounted for about $10 \%$ of China's GDP, which

Supported by the North China University of Technology outstanding young teacher training program, funded Beijing Social Science Foundation (Grant No.16LJC008)and Foundation for The Excellent Youth Scholars of Beijing(G rant No.2016000020124G021) plays a strong role in promoting the economy. The increase in demand for steel from real estate has led to a rise in the prices of steel products, as well as primary products such as iron ore and coal, which have contributed to the recovery of the world market. However, high housing prices have led to a situation that increased burden on enterprises, shrinking profit margins and drain of high-quality enterprises and brain. In the enterprise point of view, switching to the real estate industry has become an active or passive choice due to the downturn of real economic. High housing prices will higher business land, and labor costs. High prices lead to the upsurge of investment in real estate. Therefore, large private capital into the property market, while it is difficult to lend money for the lower profits of traditional industries, especially small and medium enterprises. Many small and medium enterprises have to highinterest financing by $\mathrm{P} 2 \mathrm{P}$, which resulting in rising costs and more difficult to survive. Such a vicious cycle to further increase the burden on the real economy is not conducive to the transformation and upgrading of traditional industries. From the perspective of the people, rising property prices will reduce the spending power of residents, which is not conducive to expanding domestic demand. The rise in house prices always tend to drive up rents. This has increased the pressure on businesses and employees to live on the ground. Although the staff can put forward higher requirements on wages, the cost of land is no place to digest. At the same time, the rising cost of living is difficult to reverse for employees when the housing prices have been skyrocketing.

China's "Government Work Report" of 2017 made a request to adhere to the housing properties of housing, which requires the implementation of the main responsibility of local governments to speed up the establishment and improvement of the real estate market to promote the smooth and healthy development of long-term mechanism. Up to now, nearly 20 cities of the country have introduced restriction or restriction measures to upgrade, indicating that the local government to control the rapid rise in housing prices determination. However, high housing prices can give local governments a lot of land transfer payments, tax revenue and GDP growth. It is a worthy of further study of the problem that local governments in which case can transfer financial income to consider the interests of consumers and real estate developers to maximize social welfare. 
At present, the research on the phenomenon of high housing price in our country is very rich. The main research angle is the influence factor of high house price, the reason of the result, the result of the game, and the game relationship of the real estate industry stakeholders.

With regard to the factors affecting the high housing prices, Ping Xinqiao and Chen Minyan[1]have built a panel data model. The results show that land prices, bank loans and the introduction of foreign capital are the three main factors affecting the rise in house prices. Liang Yunfang and Gao Tiemei[2]used the measurement method to study the influencing factors of house price changes. The research shows that the change of land transaction price can lead to the change of house price. However, some scholars believe that the impacts of price factors are more complex. Liu Lin and Liu Hongyu[3]believed that house prices and land prices existed mutual influence. On the one hand, rising house prices have led to an increase in land demand, which has led to an increase in land prices. On the other hand, elevation of land prices will in turn stimulate the improvement of house prices. Wang Zushan and He Lihua[4]analyzed the relationship between the high housing price and land price by using the game model and the measurement methods. They believed that the expansion of urban population size has a positive effect on rising house prices and the rise in house prices is influenced by the dual monopoly of real estate developers and local government land supply.

On the cause of high prices and the results of the study, some scholars analyzed the causes of high prices. Cao Fei [5] analyzed the causes of high house price from the perspective of public choice theory. He believed that the real estate industry policy formulation, implementation and other process of government failure led to excessive growth in house prices. Zhou Huadong and Zhou Yahong [6] constructed the panel data model of 31 provinces and cities in China and verified the conclusion that the income gap will not promote the high house prices. It is suggested that the government should strengthen the construction of low rent housing and affordable housing, so as to solve the housing problem of low-income people and improve their housing quality. Zhang Liao and Yang Chenglin [7] constructed a panel data model to test the impact of land reform on real estate prices. The results showed that the impact of land reform on the house price in China was basically the same, and the two had the inverted $U$ relationship. Other scholars did researches on the high prices of residents living, the impact of the national economy, etc. Chen Yanbin and Qiu Zhesheng[8]constructed the Bewley model to analyze the impact of high housing prices on the savings rate and the distribution of property. The results showed that high house prices will lead to demand of high-income residents for real estate investment. This increase in demand further lifted the house price. At the same time, low-income families as a result of rising housing prices to increase the savings rate, but also because prices are too high to protect their housing needs. As a result, the gap between rich and poor is growing. Pang Xiaobo, Xing Jian[9]studied the three models of high house prices exacerbating economic structural imbalance. They argued that high house prices can increase economic output in the short term, but the growth model comes from government investment. High housing prices have an adverse impact on the adjustment of China's economic structure.

In the study of the game relationship between the high house price and interest subject, Mou Lingling[10]used the method of nonlinear dynamics to study the game relationship between the government, the real estate agent and the citizen in the real estate market of China. The paper proved that the government's regulation of land prices and the regulation of real estate prices on house prices play a very important role in the game trend of Nash equilibrium. Zhou Hongyuan[11] analyzed the reasons of the high housing price from the perspective of the game relationship between the central government and local government, the game relationship between the real estate business and the local government, and the game relationship between the real estate developers and the local government. It is believed that to reduce the cost of house by breaking the monopoly of the local government in the process of land transfer is the root of solving the problem of high house prices. Chen Chao[12]analyzed the game behavior between the central government, local governments, real estate developers and consumers, and the reasons for the formation of the real estate bubble. In this paper, we use game theory to analyze the conditions of local government's choice of social welfare maximization. We also give programs about how to control the land leasing and real estate tax rates to achieve the goal of maximizing, and then find the conditions to control house prices as well as achieving the greatest social welfare for our government. This will provide the theoretical basis for the government to formulate house price control policy.

\section{MODEL}

The government is the main land transfer platform on the market. On the one hand, the government gets the land from the consumers and pays a certain amount of compensation. On the other hand, the land will be sold to the real estate developer through a certain form (recruit, shoot, hang, etc.). The government obtains a certain amount of land leasing, while collecting the real estate tax from consumers. In the whole process, the government monopolies the land supply by controlling the difference between the land price and the real estate tax rate, and the higher land leasing and the lower payment compensation. This part of the income has become a major part of the land finance. Although the land leasing and tax revenue become the main source of government finance, the government still needs to make a choice under different policy objectives. The government needs to decide whether to maximize their own fiscal revenue, or to consider the interests of consumers and real estate developers to maximize social welfare. This paper analyzes that under what conditions the government will consider the latter. And we find how to achieve the established objectives through the control of land leasing and real estate tax rates if the government considers the maximum social welfare.

\section{A. Model Setup}

There are three participants on the market, consumers, real estate developers and the government. Consumer and real estate developer utility function is: $u_{1}=v_{1}(t, p)+\theta l$, $\mathrm{u}_{2}=\mathrm{v}_{2}(\mathrm{p})-\mathrm{l}$. $\mathrm{t}$ represents the real estate tax rate. $\mathrm{p}$ represents the house price. 1 represents the land leasing (land 
price). $\theta$ represents the proportion of the government allocated to the consumers through the land leasing, $\theta \in\left[0, \frac{1}{2}\right] . v_{1}$ and $\mathrm{v}_{2}$ are second order continuous differentiable functions, $\frac{\partial \mathrm{v}_{1}}{\partial \mathrm{t}}<0$, $\frac{\partial^{2} \mathrm{v}_{1}}{\partial \mathrm{t}^{2}}>0, \frac{\partial \mathrm{v}_{1}}{\partial \mathrm{p}}<0, \frac{\partial^{2} \mathrm{v}_{1}}{\partial \mathrm{p}^{2}}>0, \frac{\partial \mathrm{v}_{2}}{\partial \mathrm{p}}>0, \frac{\partial^{2} \mathrm{v}_{2}}{\partial \mathrm{p}^{2}}<0$. House price is a function of land price: $\mathrm{p}=\mathrm{p}(\mathrm{l})$, and $\frac{\partial \mathrm{p}}{\partial \mathrm{l}}>0$. Government revenue function: $u_{3}=t p+(1-\theta) l$. Government objective function is : $g=a_{1} u_{1}+a_{2} u_{2}+(1-$ $\left.a_{1}-a_{2}\right) u_{3}$, and $a_{1}, a_{2} \in[0,1]$. It represents the allocation weight of the government in the utility of each participant.

\section{Model Analysis}

When the government takes into account the interests of the three parties at the same time, the problem(I)of maximizing social welfare is :

\section{$\mathrm{t}, \mathrm{l} \in \arg \max \mathrm{g}$}

When the government considers only the consumers and their own revenue, that is $\mathrm{a}_{2}=0$, the problem (II) of the government is:

$$
\mathrm{t}, \mathrm{l} \in \arg \max \mathrm{g}_{1}=\mathrm{a}_{1} \mathrm{u}_{1}+\left(1-\mathrm{a}_{1}\right) \mathrm{u}_{3}
$$

When the government considers only real estate developers and their own revenue, that isa ${ }_{1}=0$, the problem (III)of the government is:

$$
\mathrm{t}, \mathrm{l} \in \arg \max \mathrm{g}_{2}=\mathrm{a}_{2} \mathrm{u}_{2}+\left(1-\mathrm{a}_{2}\right) \mathrm{u}_{3}
$$

The first order necessary condition for the three problems is:

$$
\frac{\partial \mathrm{g}}{\partial \mathrm{t}}=0, \frac{\partial \mathrm{g}}{\partial \mathrm{l}}=0, \frac{\partial \mathrm{g}_{1}}{\partial \mathrm{t}}=0, \frac{\partial \mathrm{g}_{1}}{\partial \mathrm{l}}=0, \frac{\partial \mathrm{g}_{2}}{\partial \mathrm{l}}=0
$$

The optimum solution $\left(\mathrm{t}^{*}, \mathrm{l}^{*}\right)$ of the problem(I)satisfies:

$\mathrm{a}_{1} \frac{\partial \mathrm{v}_{1}}{\partial \mathrm{t}}+\left(1-\mathrm{a}_{1}-\mathrm{a}_{2}\right) \mathrm{p}=0$

$\mathrm{a}_{1}\left(\frac{\partial \mathrm{v}_{1}}{\partial \mathrm{p}} \frac{\partial \mathrm{p}}{\partial \mathrm{l}}+\theta\right)+\mathrm{a}_{2}\left(\frac{\partial \mathrm{v}_{2}}{\partial \mathrm{p}} \frac{\partial \mathrm{p}}{\partial \mathrm{l}}-1\right)+\left(1-\mathrm{a}_{1}-\mathrm{a}_{2}\right)(1-$

$$
\left.\theta+\mathrm{t} \frac{\partial \mathrm{p}}{\partial \mathrm{l}}\right)=0
$$

The optimum solution $\left(\mathrm{t}_{1}^{*}, \mathrm{l}_{1}^{*}\right)$ of the problem(II)satisfies:

$$
\begin{aligned}
& \mathrm{a}_{1} \frac{\partial \mathrm{v}_{1}}{\partial \mathrm{t}}+\left(1-\mathrm{a}_{1}\right) \mathrm{p}=0 \\
& \mathrm{a}_{1}\left(\frac{\partial \mathrm{v}_{1}}{\partial \mathrm{p}} \frac{\partial \mathrm{p}}{\partial \mathrm{l}}+\theta\right)+\left(1-\mathrm{a}_{1}\right)\left(1-\theta+\mathrm{t} \frac{\partial \mathrm{p}}{\partial \mathrm{l}}\right)=0
\end{aligned}
$$

The optimum solution( $\left(\mathrm{t}_{2}^{*}, \mathrm{l}_{2}^{*}\right)$ of the problem(III)satisfies:

$$
\begin{aligned}
& \mathrm{t}_{2}^{*} \rightarrow+\infty \\
& \mathrm{a}_{2}\left(\frac{\partial \mathrm{v}_{2}}{\partial \mathrm{p}} \frac{\partial \mathrm{p}}{\partial \mathrm{l}}-1\right)+\left(1-\mathrm{a}_{2}\right)\left(1-\theta+\mathrm{t} \frac{\partial \mathrm{p}}{\partial \mathrm{l}}\right)=0
\end{aligned}
$$

Theorem 1: The optimal real estate tax rate $t^{*}$ that the government considers the maximization of overall social welfare less than or equal to the tax rate $t_{1}^{*}$ that the government does not take into account the interests of real estate developers.

Prove: We define a function: $h(t)=-\frac{\partial v_{1}}{\partial t}$, because: $\frac{\partial \mathrm{v}_{1}}{\partial \mathrm{t}}<0$, so: $\frac{\partial \mathrm{h}(\mathrm{t})}{\partial \mathrm{t}}>0$.
The formula (4) shows that $\left(\mathrm{t}^{*}, \mathrm{l}^{*}\right)$ satisfies: $\mathrm{h}\left(\mathrm{t}^{*}\right)=$ $\frac{1-a_{1}-a_{2}}{a_{1}} p$.

The formula (6) shows that $\left(\mathrm{t}_{1}^{*}, \mathrm{l}_{1}^{*}\right)$ satisfies: $\mathrm{h}\left(\mathrm{t}_{1}^{*}\right)=\frac{1-\mathrm{a}_{1}}{\mathrm{a}_{1}} \mathrm{p}$.

When $\mathrm{a}_{2} \in[0,1]$, that ish $\left(\mathrm{t}^{*}\right) \leq \mathrm{h}\left(\mathrm{t}_{1}^{*}\right)$, $\operatorname{sot}^{*} \leq \mathrm{t}_{1}^{*}$.

The theorem suggests that the government should set a lower real estate tax rate if the goal is to maximize the overall social welfare.

Theorem 2: When $\mathrm{t} \leq \frac{\partial \mathrm{v}_{2}}{\partial \mathrm{p}}$, the optimal land leasingl ${ }^{*}$ that the government considers the maximization of social welfare less than or equal to the land leasing $l_{1}^{*}$ that the government does not take into account the interests of real estate developers.

Prove: We define a function: $\mathrm{h}(\mathrm{t})=-\frac{\partial \mathrm{v}_{1}}{\partial \mathrm{t}}$, because: $\frac{\partial \mathrm{p}}{\partial \mathrm{l}}>0$, so: $\frac{\partial \mathrm{s}(\mathrm{l})}{\partial \mathrm{l}}>0$.

The formula (5) shows that $\left(\mathrm{t}^{*}, \mathrm{l}^{*}\right)$ satisfies: $\mathrm{s}\left(\mathrm{l}^{*}\right)=$ $\mathrm{a}_{2}\left(1-\theta+\mathrm{t} \frac{\partial \mathrm{p}}{\partial \mathrm{l}}\right)-\mathrm{a}_{2}\left(\frac{\partial \mathrm{v}_{2}}{\partial \mathrm{p}} \frac{\partial \mathrm{p}}{\partial \mathrm{l}}-1\right)=\mathrm{a}_{2}\left[\left(\mathrm{t}-\frac{\partial \mathrm{v}_{2}}{\partial \mathrm{p}}\right) \frac{\partial \mathrm{p}}{\partial \mathrm{l}}-\theta\right]$.

The formula (7) shows that $\left(\mathrm{t}_{1}^{*}, \mathrm{l}_{1}^{*}\right)$ satisfies: $\mathrm{s}\left(\mathrm{l}_{1}^{*}\right)=0$.

When $\mathrm{a}_{2} \in[0,1], \mathrm{t} \leq \frac{\partial \mathrm{v}_{2}}{\partial \mathrm{p}}$, that is $\mathrm{s}\left(\mathrm{l}^{*}\right) \leq \mathrm{s}\left(\mathrm{l}_{1}^{*}\right)$, $\mathrm{sol}^{*} \leq \mathrm{l}_{1}^{*}$.

The theorem shows that if the government's real estate tax rate is less than the increase of marginal utility of real estate developers brought by house price, the government should reduce the collection of land leasing to achieve the maximization of social welfare. In essence, it is to increase the interests of real estate developers by reducing the land leasing and to increase the interests of customers by lowering the tax rates.

Theorem 3: When $t \geq \frac{\partial \mathrm{v}_{1}}{\partial \mathrm{p}}$, the optimal land leasingl ${ }^{*}$ that the government considers the maximization of social welfare loss than or equal to the land leasing $\mathrm{l}_{2}^{*}$ that the government does not take into account the interests of customers.

Prove: We define a function: $\mathrm{k}(\mathrm{l})=\mathrm{a}_{2}\left(\frac{\partial \mathrm{v}_{2}}{\partial \mathrm{p}} \frac{\partial \mathrm{p}}{\partial \mathrm{l}}-1\right)+$ $\left(1-\mathrm{a}_{2}\right)\left(1-\theta+\mathrm{t} \frac{\partial \mathrm{p}}{\partial \mathrm{l}}\right)$, because: $\frac{\partial \mathrm{v}_{2}}{\partial \mathrm{p}}>0, \frac{\partial \mathrm{p}}{\partial \mathrm{l}}>0$, so $\frac{\partial \mathrm{k}(\mathrm{l})}{\partial \mathrm{l}}>0$.

The formula (5) shows that $\left(\mathrm{t}^{*}, \mathrm{l}^{*}\right)$ satisfies: $\mathrm{k}\left(\mathrm{l}^{*}\right)=$ $\mathrm{a}_{1}\left(1-\theta+\mathrm{t} \frac{\partial \mathrm{p}}{\partial \mathrm{l}}\right)-\mathrm{a}_{1}\left(\frac{\partial \mathrm{v}_{1}}{\partial \mathrm{p}} \frac{\partial \mathrm{p}}{\partial \mathrm{l}}+\theta\right)=\mathrm{a}_{1}\left[\left(\mathrm{t}-\frac{\partial \mathrm{v}_{1}}{\partial \mathrm{p}}\right) \frac{\partial \mathrm{p}}{\partial \mathrm{l}}+1-\right.$ $2 \theta]$.

The formula (9) shows that $\left(\mathrm{t}_{2}^{*}, \mathrm{l}_{2}^{*}\right)$ satisfies: $\mathrm{k}\left(\mathrm{l}_{2}^{*}\right)=0$.

When $\mathrm{a}_{1} \in[0,1], \quad \theta \in\left[0, \frac{1}{2}\right], \quad \mathrm{t} \geq \frac{\partial \mathrm{v}_{1}}{\partial \mathrm{p}}$, that is $\mathrm{k}\left(\mathrm{l}^{*}\right) \geq$ $\mathrm{k}\left(\mathrm{l}_{2}^{*}\right)$, so $\mathrm{l}^{*} \geq \mathrm{l}_{2}^{*}$.

The theorem shows that if the government's real estate tax rate is greater than the decrease of marginal utility of consumers brought by house price, the government should improve the collection of land leasing to achieve the maximization of social welfare. In essence, it is to increase the interests of customers by increasing the land leasing and to increase government revenue by raising the tax rates. 


\section{CONCLUSIONS}

This paper constructs a game model between government, real estate developers and consumers. We know the government chooses the latter between the choice of two kinds of decisions, which is to maximize their own financial income or maximize social welfare. We also analyze the policy implications of the land price and the real estate tax rate in order to achieve the stated goal. The main conclusions are as follows:

The tax rate that the government does not consider the interests of real estate developers is greater than the optimal real estate tax rate that the government considers the overall social welfare maximization. Therefore, if the government wants to achieve the greatest overall social welfare, it is necessary to develop a lower real estate tax rate.

When $t \leq \frac{\partial v_{2}}{\partial p}$, the optimal land leasing that the government considers the maximization of social welfare loss than or equal to the land leasing that the government does not take into account the interests of real estate developers. The economic meaning is that if the government's real estate tax rate is less than the increase of marginal utility of real estate developers brought by house price, the government should reduce the collection of land leasing to achieve the maximization of social welfare. In essence, it is to increase the interests of real estate developers by reducing the land leasing and to increase the interests of customers by lowering the tax rates.

When $t \geq \frac{\partial v_{1}}{\partial p}$, the optimal land leasing that the government considers the maximization of social welfare loss than or equal to the land leasing that the government does not take into account the interests of customers. The economic meaning is that if the government's real estate tax rate is greater than the decrease of marginal utility of consumers brought by house price, the government should improve the collection of land leasing to achieve the maximization of social welfare. In essence, it is to increase the interests of customers by increasing the land leasing and to increase government revenue by raising the tax rates.

\section{REFERENCES}

[1] Ping Xinqiao, Chen Minyan. Financing, land prices and real estate prices [J]. World Economy, 2004, (7):3-10. (In Chinese)

[2] Liang Yunfang, Gao Tiemei. An empirical analysis on the causes of price fluctuation in commercial housing of China [J]. Managing the World, 2006(8):76-82. (In Chinese)

[3] Liu Lin, Liu Hongyu. The economic analysis of the relationship between land price and house price [J]. Quantitative Economic and Technological Economics,2013 (7): 27-30. (In Chinese)

[4] Wang Zushan, He Lihua. Analysis of the relationship between land price and high house price - Theory and evidence [J]. Discussion on Modern Economy,2015 (1): 18-22. (In Chinese)

[5] Cao Fei, the analysis of the causes of high housing prices from the perspective of public choice theory [J]. Economic system reform, 2013 (1): 27-31. (In Chinese)

[6] Zhou Huadong, Zhou Yahong. Is the income gap driving our house prices up in China? [J]. Industrial Economics Research, 2015 (4): 81-90. (In Chinese)

[7] Zhang Liao, Yang Chenglin. Does land market reform stabilize house price volatility? [J]. Economist, 2015 (12): 34-41. (In Chinese)

[8] Chen Yanbin, Qiu Zhe Sheng. How do high housing prices affect household savings and property inequality? [J]. Economic Research, 2011 (10): 25-39. (In Chinese)

[9] Pang Xiaobo, Xing Jian. How to exacerbate economic structural imbalance in high house prices? [J]. Research on Economic Issues, 2012 (12): 66-75. (In Chinese)

[10] Mou Lingling.Nonlinear game model of real estate market and its internal complexity [D]. Tianjin: Tianjin University, 2007. (In Chinese)

[11] Zhou Hongyuan, Based on the theory of high house prices due to bargain research [D]. Zhengzhou: Zhengzhou University, 2011. (In Chinese)

[12] Chen Chao, Liu Zijun, Xiao Hui. On the "dilemma" of real estate market of China from the perspective of supply [J]. Financial Research, 2011 (1): 73-93. (In Chinese) 